\title{
Peranan Faktor Promosi Dalam Memasarkan Produk Terhadap Perilaku Pembelian Online Di Masa Pandemi Covid-19 (Studi Kota Tanjungpinang)
}

\author{
Iranita \\ Program Studi Manajemen, Fakultas Ekonomi, Universitas Maritim Raja Ali Haji
}

\begin{abstract}
ABSTRAK : Kondisi pandemi corona COVID-19 yang diikuti dengan penerapan social distancing memunculkan perilaku konsumen baru, tetapi di satu sisi ternyata membuka peluang bagi bisnis perbankan, finansial, dan jasa keuangan untuk memacu pemasaran. Salah satu hasil analisa ialah situasi pandemi rupanya memunculkan perilaku konsumen baru. Para pelaku bisnis mengoptimalkan pemasaran online dan digital branding sebagai sarana komunikasi dengan target konsumennya. Didukung dengan Pertumbuhan teknologi informasi yang sangat pesat telah menciptakan peluang bisnis baru dalam mengejar kesuksesan usahanya. Tujuan dari penelitian ini adalah untuk mengetahui peranan faktor promosi terhadap perilaku pembelian online masa COVID-19. Penelitian ini bersifat explanatory research dengan menggunakan analisis faktor. Dalam penelitian ini jumlah variabel yang ditetapkan adalah 7 variabel yang berhubungan dengan faktor faktor promosi dalam terhadap perilaku pembelian online masa pandemic COVID-19. Hasil dari penelitian ini adalah faktor promosi, adalah satu-satunya faktor yang kuat dalam mempengaruhi perilaku pembelian online masa COVID-19 di Tanjungpinang, dimana Pertumbuhan perkembangan teknologi apalagi di masa COVID-19 telah mendorong webonline memicu antusiasme untuk mengembangkan promosi pelanggan yang responsive
\end{abstract}

\section{Kata Kunci: Promosi, Perilaku Pembelian Online}

\begin{abstract}
The COVID-19 pandemic followed by the implementation of social distancing gave rise to new consumer behavior, but on the one hand it turned out to open opportunities for banking, financial, and financial services businesses to spur marketing. One of the results of the analysis is that the pandemic situation apparently gave rise to new consumer behavior. Businesses optimize online marketing and digital branding as a means of communication with their target customers. Supported by the rapid growth of information technology has created new business opportunities in pursuit of business success. The purpose of this study is to find out the role of promotional factors towards online purchasing behavior during COVID-19. This research is explanatory research using factor analysis. In this study, the number of variables set was 7 variables related to factors related to the behavior of online purchases during the COVID-19 pandemic. The results of this study are promotional factors, is the only strong factor in influencing the behavior of online purchases during COVID-19 in Tanjungpinang, where the growth of technology developments especially in the COVID19 period has driven webonline sparking enthusiasm to develop responsive customer promotions
\end{abstract}

Keywords: Promotions, Online Purchasing Behavior

Email Address : iranita@umrah.ac.id

\section{PENDAHULUAN}

\section{Latarbelakang}

Dampak pandemi virus corona (Covid-19) sangat terasa di dunia bisnis dan ekonomi. Dalam waktu yang cukup singkat, pola pemasaran pun berubah terlebih ketika diberlakukan social distancing dan Pembatasan Sosial Berskala Besar (PSBB).

Ada beberapa sektor bisnis yang berpotensi stabil dan mengalami kenaikan seperti produk kesehatan yang dibutuhkan saat pandemi, $e$ commerce, minimarket, toko sembako, apotek, toko jamu, provider internet, jasa penyedia video conference, aplikasi belajar dari rumah, dan lainnya.

Untuk bisa bertahan di tengah pandemi ini, para pelaku brand harus bisa menyisiatinya, karena di tengah pandemi ini ada ancaman sekaligus peluang. Bagi pemasar tentunya bisa menangkap peluang tersebut. 
Kondisi pandemi corona COVID-19 yang diikuti dengan penerapan social distancing memunculkan perilaku konsumen baru, tetapi di satu sisi ternyata membuka peluang bagi bisnis perbankan, finansial, dan jasa keuangan untuk memacu pemasaran. Salah satu hasil analisa ialah situasi pandemi rupanya memunculkan perilaku konsumen baru, yang berbeda-beda di setiap negara Asia Tenggara. Saat ini merupakan saat yang tepat bagi bisnis perbankan, finasial dan service keuangan untuk melakukan pemasaran.Para kalangan industri dapat memanfaatkan ruang digital untuk melakukan promosi kepada pengguna loyal, bahkan menjangkau pengguna baru.

Berdasarkan Survei Sosial Demografi, dampak Covid-19 yang digelar Badan Pusat Statistik (BPS), dimana 54 dari 100 responden generasi milenial yang berbelanja online selama pandemic COVID19 merupakan perempuan. Sekitar $45 \%$ responden generasi milenial berjenis kelamin perempuan memilih tetap tinggal di rumah dengan alasan menjaga kesehatan diri dan keluarga. Ini membuat perempuan milenial lebih memilih belanja online dibandingkan laki-laki," ujar Kepada BPS Suhariyanto seperti dikutip dari hasil Survei Sosial Demografi Covid-19.

Pemerintah sendiri telah menetapkan masa bencana darurat Covid-19 dan belum ada batas waktu kapan pandemic ini akan berkahir. Tentunya, para pemasar perlu menyikapinya dengan membuat strategi yang tepat, baik saat masa pandemi berlangsung maupun setelah pandemi berakhir.

Dalam situasi seperti ini, banyak perusahaan dan brand menahan aktivitas pemasarannya untuk sementara waktu. Beberapa bahkan menahan aktivitas tersebut hingga situasi mulai normal dan terkendali. Hal ini menyebabkan berkurangnya aktivitas pemasaran secara umum.

Pemasar harus putar otak untuk bisa memasarkan produk atau jasa mereka ke konsumen, sebagai strategi brand bertahan di tengah pandemi virus corona. Para pelaku bisnis mengoptimalkan pemasaran online dan digital branding sebagai sarana komunikasi dengan target konsumennya. Didukung dengan Pertumbuhan teknologi informasi yang sangat pesat telah menciptakan peluang bisnis baru dalam mengejar kesuksesan usahanya

Perusahaan menggunakan teknik pemasaran modern seperti onlinemarketing, viralmarketing, pemasaran mesin pencari (search engine marketing) dan e-mailmarketing akan lebih berhasil dalam memenuhi kompetisi (Gautam, 2012). Melalui pemasaran online, semakin mudah isi website diakses yang berkaitan dengan produk dan jasa yang ditawarkan, maka semakin besar pula kemungkinan bahwa produk dan layanan jasa tersebut akan dibeli oleh konsumen menurut Taylor dan England dalam Partha dan Sukawati, 2016). Konsumen dapat mencari informasi produk di Internet sebelum membuat keputusan pembelian secara online (Lo, et al., 2013).

Pertumbuhan perkembangan teknologi apalagi di masa COVID-19 telah mendorong webonline memicu antusiasme untuk mengembangkan promosi pelanggan responsive (Chatterjee \& McGinnis, 2010). Usaha perusahaan untuk mempengaruhi calon pembeli melalui pemakaian segala unsur atau bauran pemasaran akan menghasilkan daya tarik promosi yang membuat konsumen semakin tertarik untuk membeli barang atau jasa yang ditawarkan (Putra \& Kusuma, 2015)

Melihat permasalah tersebut, para pelaku bisnis harus menyikapinya dengan cepat dan tepat untuk mengubah strategi penjualannya. Diharapkan tidak terjadi drop penjualan yang signifikan saat diberlakukannya social distancing.

\section{Tujuan Penelitian}

Berdasarkan rumusan masalah yang telah disebutkan sebelumnya maka penelitian ini bertujuan untuk menganalisis dan mengetahui Peranan Faktor promosi dalam memasarkan produk terhadap prilaku pembelian online masa pandemi COVID-19 di Tanjungpinang

\section{Promosi}

Memasarkan suatu produk perusahaan pasti memerlukan promosi dalam memperkenalkan produknya kepada konsumen. Promosi yang dilakukan perusahaan bermaksud untuk memasarkan, memberikan informasi tentang 
kelebihan-kelebihan produk tersebut. Promosi yang digunakan biasanya seperti media televisi, radio, poster dan lain-lain yang bertujuan untuk menarik minat konsumen

\section{Pengertian Promosi}

Promosi merupakan salah satu bentuk kegiatan pemasaran yang bertujuan untuk menginformasikan kepada pasar untuk keberadaan suatu produk baru. Promosi dapat memberitahukan kepada konsumen mengenai manfaat produk, kualitas produk maupun hal-hal lainnya yang bersangkutan dengan promosi."Promosi merupakan salah satu variable dalam bauran pemasaran yang sangat penting dilaksanakan oleh perusahaan dalam memasarkan suatu produk. Sanjaya, (2015).

Hal ini didukung pendapat dari Dedy dan Dita (2015) bahwa Promosi adalah suatu bentuk komunikasi pemasaran, yang merupakan aktivitas pemasaran yang berusaha menyebarkan informasi, mempengaruhi/ membujuk, dan/ atau mengingatkan pasar sasaran atas perusahaan dan produknya agar bersedia memberi keputusan dalam menerima, membeli, dan loyal pada prosuk yang ditawarkan perusahaan yang bersangkutan

\section{Jenis-jenis Promosi}

Jenis-jenis promosi menurut Handoko (2014) adalah sebagai berikut:

1. Periklanan (advertising)

Bentuk presentasi yang bukan personal dan promosi atas gagasan, barang atau jasa oleh seseorang atau sponsor yang teridentifikasi dalam media. Menurut Kotler dan Armstrong (2013) bahwa tujuan periklanan adalah komunikasi tertentu yang dicapai dengan calon konsumen pada sasaran tertentu dan selama periode waktu tertentu. Tujuan dari periklanan itu bisa digolongkan berdasarkan tujuan utama yaitu menginformasikan (informing) membujuk persuading), dan mengingatkan (reminding).

2. Promosi Penjualan (Sales Promotion) Yaitu kegiatan pemasaran selain penjualan pribadi, iklan dan publikasi yang menstimulasi pembelian konsumen serta efektifitas penyalur yang mempunyai jangka waktu pendek. Menurut Kotler dan Armstrong banyak sarana yang dapat digunakan untuk mencapai tujuan promosi penjualan

3. Alat Promosi Konsumen

Meliputi contoh produk, kupon, cashback, harga khusus, premi, barang khusus iklan, undian, serta permainan

4. Alat Promosi Dagang

Penjual perantara untuk menjual merek, memberikan ruang gerak dan mempromosikan merek itu dalam iklan yang pada akhirnya menawarkannya kepada konsumen. Beberapa alat promosi dagang yang biasanya digunakan oleh produsen adalah kontes, diskon langsung dari harga resmi, produk gratis yang berupa kemasan ekstra yang ditujukan kepada penjualperantara yang membeli dalam jumlah tertentu

5. Promosi Bisnis (Business Promotion)

Alat promosi penjualan yang digunakan untuk menghasilkan tujuan bisnis, meningkatkan jumlah penjualan, menghargai pelanggan serta memotivasi penjual. Dalam hal ini perusahaan fokus pada dua alat tambahan komponen promosi bisnis utama yaitu konvensi dan pameran dagang. Perusahaan yang menjual produk mereka menampilkan keunggulan produkmereka pada sebuah pameran dagang

6. Hubungan Masyarakat (Public relation)

Berhubungan dengan sejumlah usaha dalam berkomunikasi untuk mendukung sikap dan pendapat publik terhadap organisasi serta produknya. Public relations dapat dilakukan dengan menyampaikan secara lengkap tentang informasi perusahaan atau produk. Menurut Kotler dan Armstrong hubungan 
masyarakat dapat dilaksanakan satu atau semua fungsi

Komunikasi pemasaran perlu juga ditampilkan secara lugas dan menarik guna membujuk calon konsumen agar berminat membeli produk yang ditawarkan. Kotler dan Keller (2013) mengemukakan bahwa salah bentuk komunikasi pemasaran adalah iklan (promosi) yang harus memiliki kemenarikan khas yang mampu membuat calon konsumen tertarik pada produk yang ditawarkan. Untuk ini, fungsi iklan tersebut adalah harus mampu menginformasikan manfaat produk yang ditawarkan, memunculkan rasa percaya dan menarik hati para calon konsumen. Sebuah desain website, sebagai salah satu cara mewujudkan daya tarik iklan. Dikatakan menarik apabila isi dan tampilannya mampu menarik pasar sasaran mampu menarik minat para clickers dalam akun tersebut.

Sarwono dan Prihartono (2012) mengemukakan bahwa teknik yang memudahkan akses dan publikasi informasi adalah menggunakan interaksi sosial melalui sosial media. Diseminasi informasi melalui sosial media selain mulai menjamur karena tingginya ikatan sosial dari pengguna juga merupakan cara baru yang lebih efektif dalam pencarian informasi.

Dalam penyebaran informasi inilah, kemenarikan desain website menjadi salah satu pemandu yang handal gu-na mendorong calon konsumen untuk mengunjungi akun yang ada. Oleh karenanya semakin menarik desain website diharapkan mampu memantabkan kepu-tusan berbelanja online. Selain itu kemenarikan desain website akan memengaruhi keinginan seseorang dalam melakukan belanja online. Keinginan tersebut merupakan perwujudan dari kepercayaan seseorang atas transaksi yang dilakukan.

\section{Indikator Promosi}

Tujuan dasar dilaksanakannya promosi adalah untuk mempengaruhi konsumen supaya membeli produk yang dihasilkan penjual. Suatu promosi yang dilaksanakan tanpa mempunyai tujuan sama saja dengan melaksanakan pekerjaan yang sia-sia. Tujuan promosi merupakan dasar dalam membuat keseluruhan program promosi yang akan dijalankan oleh perusahaan dalam rangka mencapai apa yang diinginkannya, kemudian akan menyusun langkahlangkah selanjutnya.

Sedangkan indikator Promosi menurut Kotler dan Keller (2013) adalah sebagai berikut:

1. Kuantitas Promosi

Adalah nilai atau jumlah promosi penjualan yang diberikan kepada konsumen.

2. Kualitas Produk

Adalah tolak ukur seberapa baik promosi penjualan dilakukan

3. Waktu Promosi

Adalah lamanya promosi yang dilakukan perusahaan

4. Ketepatan atau kesesuaian sasaran promosi. Merupakan faktor yang diperlukan untuk mencapai target yang diinginkan.

\section{Perilaku Konsumen}

Menurut Kotler (2013: 166) Perilaku konsumen merupakan studi tentang bagaimana individu, kelompok, dan organisasi memilih, membeli, menggunakan, dan bagaimana barang, jasa, ide atau pengalaman untuk memuaskan kebutuhan keinginan mereka. Menurut Tjiptono (2014: 56) Perilaku konsumen (Consumer behavior) adalah aktivitas-aktivitas individu dalam pencarian, pengevaluasian, pemerolehan, pengkonsumsian, dan penghentian pemakaian barang dan jasa

\section{Sikap Belanja Online}

Menurut Kotler dan Keller (2013) menjelaskan bahwa proses pengambilan keputusan selalu berhubungan dengan situasi yang tidak terduga dan sikap terhadap pembelian.

Belanja online menurut beberapa ahli, penulis menyimpulkan belanja online merupakan suatu aktivitas transaksi elektronik yang dilakukan konsumen melalui toko online secara langsung melalui suatu alat yang terkonektifitas dengan internet dengan berbagai media seperti ; komputer, laptop, hanphone dan lainnya.

Perilaku belanja online mengacu pada proses pembelian produk dan jasa melalui internet. Maka 
pembelian secara online telah menjadi alternatif pembelian barang ataupun jasa. Penjualan secara online berkembang baik dari segi pelayanan, efektifitas, keamanan, dan juga popularitas. Pada zaman sekarang berbelanja secara online bukanlah hal yang asing. Konsumen tidak perlu mengeluarkan banyak tenaga saat berbelanja online, cukup dengan melihat website bisa langsung melakukan transaksi pembelian.

Salah satu faktor yang memengaruhi perilaku pembelian online konsumen adalah persepsi manfaat. Menurut Kim, Ferrin, \& Rao dalam Ansari dan Dita (2018) bahwa persepsi manfaat merupakan keyakinan konsumen tentang sejauh mana ia akan menjadi lebih baik dari transaksi online dengan situs web tertentu.

Konsep dari kata manfaat mengacu pada sejauh mana suatu inovasi dianggap lebih baik untuk menggantikan gagasan yang telah ada menurut Rogers dalam Ansari dan Dita (2018). Misalnya, manfaat dari berbelanja melalui website mencerminkan pengakuan konsumen bahwa metode belanja baru ini memberikan manfaat tertentu sebagai format belanja alternatif. Karayanni dalam Ansari dan Dita (2018). mengatakan bahwa jika seorang pelanggan percaya bahwa ia akan mendapatkan keuntungan yang lebih besar ketika membeli online daripada membeli melalui toko konvensional, maka ia tentu lebih memilih opsi belanja ini dalam pemenuhan kebutuhannya.

Forsythe, Liu, Shannon, \& Gardner dalam Ansari dan Dita (2018). menemukan adanya hubungan positif dan signifikan antara persepsi manfaat pembelian melalui internet dengan frekuensi pembelian dan waktu yang digunakan untuk pencarian online. Farag \& Lyons dalam Ansari dan Dita (2018), menemukan bahwa pencarian online dan persepsi manfaat memberikan efek positif terhadap frekuensi belanja, dan hal ini memberikan efek positif pula terhadap pembelian online. Hal ini menunjukkan bahwa persepsi manfaat terhadap pembelian online akan memengaruhi perilaku pembelian yang dilakukan konsumen.
Rahayuningsih, Prasad dan Aryasri dalam Widiyanto dan Sri (2015) mengemukakan bahwa sikap merupakan suatu bentuk perasaan yang bersifat favourable atau unfavourable. Dengan demikian, sikap pada dasarnya menunjukkan kondisi mental atau pun rasionalitas tertentu yang mencerminkan suatu pandangan pribadi mengenai suatu objek atau-pun konsep. Pandangan tersebut dapat berupa pandangan yang positif (bermanfaat) dan pandangan negatif (destruktif). Kim, Ferrin, \& Rao, dan Shim, Eastlick, Lotz, \& Warrington dalam selanjut-nya menjelaskan bahwa sikap belanja online di sini merupakan faktor penyebab yang sangat penting da-lam proses pengambilan keputusan pembelian online.

Selanjutnya Rahayuningsih, Prasad dan Aryasri dalam Widiyanto dan Sri (2015) bahwa sikap belanja online Perasaan konsumen manakala melakukan belanja online berdasarkan beberapa indicator dibawah ini:

1. Suka dengan belanja online

2. Nyaman saat melakukan belanja online

3. Percaya dengan kebenaran proses transaksi

\section{Kerangka Konseptual}

Dari perjelasan yanag telah diuraikan sebelumnya, maka dalam penelitian ini dapat diambil gambaran konsep pemikiran yang dituangkan pada gambar di bawah ini:

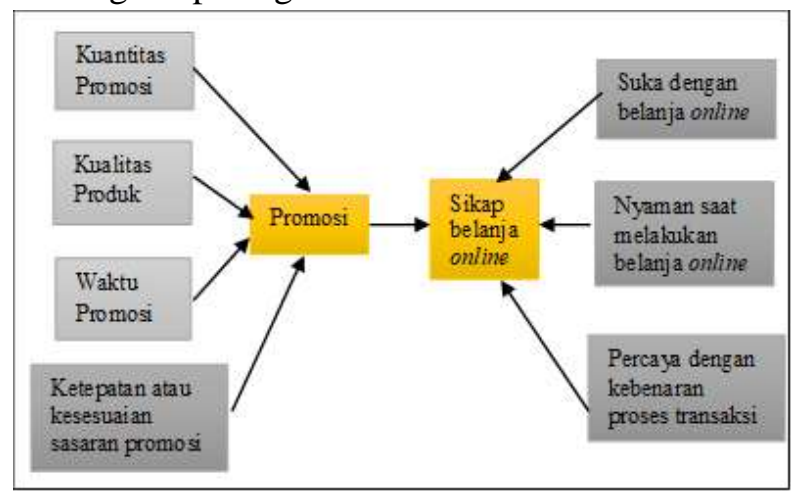

Gambar 1. Kerangka Konseptual

\section{METODE PENELITIAN}

\section{Desain Penelitian}

Pada penelitian ini peneliti mengambil lokasi di sekitar kota Tanjungpinang, dimana objek utama 
konsumen yang pernah melakukan pembelian online selama COVID-19

Penelitian yang digunakan disini adalah penelitian yang bersifat eksplorasi (explanatory research) yaitu penelitian yang menggali dan menganalisis Peranan Faktor Promosi dalam mempengaruhi Perilaku pembelian online.

Metode pengumpulan data pada dasarnya ada 3 macam, yaitu sensus, sampling, dan studi kasus (case study). Pada penelitian ini digunakan metode sampling atau survei. Dimana metode pengumpulan data merupakan cara kerja yang bersistem dalam mengumpulkan data untuk mencapai tujuan penelitian, yang dilakukan melalui survei dan analisa karena penelitian merupakan aktivitas ilmiah yang sistematis, terarah dan bertujuan,dengan melakukan wawancara dan kuesioner.

\section{Populasi Dan Sampel}

Pengumpulan data pada penelitian ini menggunakan metode survei. Teknik pengumpulan data pri-mer dilakukan dengan non-probability sampling de-sign karena luasnya populasi penelitian. Teknik pe-ngambilan sampel yang digunakan adalah mengkombinasi purposive sampling dan convenience sampling. Kriteria purposive sampling yaitu individu yang pernah melakukan transaksi belanja online untuk dikonsumsi/digunakan sendiri selama masa Pandemi COVID-19 ini. Untuk ini, angket didesain menyaring responden dengan mensyaratkan pernah bertransaksi secara online. Karena teknik survei dilakukan secara online, pengambilan sampel kemudian dikombinasikan dengan convenience sampling. Lokasi penelitian adalah di Kota Tanjungpinang. Pengambilan sampel yang penulis lakukan adalah menggunakan Accidental Sampling yaitu teknik penentuan sampel berdasarkan kebetulan bertemu dengan responden dapat digunakan sebagai sampel, bila dipandang orang yang kebetulan ditemuinya itu cocok sebagai sumber data (Sugiono, 2014).

Digunakan teknik acidental sampling tersebut adalah dengan pengertian bahwa tidak mungkin semua populasi dapat di interview, karena keterbatasan tenaga, waktu dan biaya, anggota populasi lainnya dianggap homogen. Homogen dalam pengertian sampel ini individu yang pernah melakukan transaksi belanja online untuk dikonsumsi/digunakan sendiri selama masa Pandemi Covid-19. Setelah dilakukan perhitungan diperoleh sampel sebanyak 100 responden.

\section{Pengumpulan Data}

Kuesioner disebarkan kepada 100 konsumen individu yang pernah melakukan transaksi belanja online untuk dikonsumsi/digunakan sendiri selama masa Pandemi COVID-19. Hasilnya didapat peranan apa saja yang bisa mendukung untuk memasarkan produk masa COVID-19 yang menurut konsumen mempengaruhi prilaku pembelian mereka secara online..

\section{Metode Analisis}

Untuk menjawab masalah dan mengungkap tujuan penelitian ini analisis yang digunakan adalah analisis faktor yang digunakan untuk mengetahui peranan faktor-faktor promosi dalam memasarkan produk pada masa COVID-19 terhadap Prilaku pembelian online.

Analisis faktor yaitu suatu metode reduksi data untuk menemukan variabel baru yang disebut faktor yang jumlahnya lebih sedikit dibandingkan dengan jumlah aslinya, yang tidak berkorelasi satu sama lainnya, variabel baru tersebut memuat sebanyak mungkin informasi yang terkandung di dalam variabel asli (Kuncoro,2009)

Menurut Sarwono (2006) Model analisis faktor dinyatakan dengan formula sebagai berikut :

$\mathrm{Xi}=\mathrm{Aij}+\mathrm{Ai} 2 \mathrm{~F} 2+\mathrm{Ai} 3 \mathrm{~F} 3 \ldots .+\mathrm{AimFm}+$ ViUi dimana :

$\mathrm{Xi}=$ Variable standar yang ke- $\mathrm{i}$

Aij = Koefisien Multiple Regresi Standar dari variabel ke-i pada common faktor j

$\mathrm{F}=$ Common Factor

$\mathrm{Vi}=$ Koefisien regresi berganda standar dari variabel-i pada faktor unik-i

$\mathrm{Ui}=$ Faktor unik variabel-i 
$\mathrm{m}$ = Banyaknya common factor Faktor unik berkorelasi satu dengan yang lain dan dengan common factor.

Common factor dapat dinyatakan sebagai kombinasi linier dari variabel yang diteliti, dengan persamaaan :

$\mathrm{Fi}=\mathrm{Wi} 1 \mathrm{X} 1+\mathrm{Wi} 2 \mathrm{X} 2+\mathrm{Wi} 3 \mathrm{X} 3+\ldots . .+$ WikXk dimana :

$\mathrm{Fi}=$ Faktor ke-i yang diestimasi

$\mathrm{Wi}=$ Bobot atau koefisien score factor

$\mathrm{Xk}=$ Banyaknya variabel $\mathrm{X}$ pada faktor ke $\mathrm{k}$

\section{Statistik Yang Terkait Analisis Faktor}

Prosedur melakukan Analisis Faktor :

- Barlett's test of sphrecity. Uji yg dugunakan utk menguji hipotesis bhw variabel2 tdk saling berkorelasi $\mathrm{dlm}$ populasi. Matriks korelasi populasi mrpkn matriks identitas, setiap varibael berkorelasi scr sempurna dg dirinya sendiri $(r=1)$ dan tidak berkorelasi dg yg lain $(\mathrm{r}=0)$

- Factor loading (muatan faktor). Merupakan korelasi sederhana antara variabel2 dgn faktor2 atau antara variabel baru dgn variabel yg diwakilinya

- Eigen Value (nilai eigen). Nilai eigen mewakili varians total yg dijelaskan oleh setiap faktor. Dilihat dr R2 => berapa \% varian dr sejumlah varian dpt dijelskan dgn faktor. Mis: Variabel 1 memiliki hub yg kuat dgn faktor 1

Mis: hub F1 dgn V1 V2 V3 adl R2 $=0.81$ Maka faktor 1 dpt menjelaskan V1 V2 V3 sebesar $81 \%$

- Rotasi. Memutar faktor yg ada agar memudahkan interpretasi.

- Component matrix. Utk melihat variabel2 mana yg masuk dlm komponen 1 atau 2

- Kaiser Meyer Olkin (KMO). Ukuran sampling KMO menetukan apakah variabel2 yg kita uji bisa dianalisis atau tidak. Jika nilai dibaah 0,5 maka tidak bisa dianalisis. Nilai tinggi $(0,5-$ 1) $\Rightarrow>$ analisis faktor telah cukup. Nilai $<0,5=>$ analisis faktor tidak cukup
- Anti image matrix. Yaitu cara melihat diagonal ke bawah atau ke atas. Jika nilai anti images nya kurang dari 0.5 maka variabel tsb harus dibuang. Maka prosesnya harus diulang, dibuang satu per satu hingga tdk ada nilai yg dibawah 0,5

\section{Tahapan Analisis Faktor}

1. Tabulasi data pada data view,

2. Pembentukan matrik korelasi,

3. Ekstraksi faktor,

4. Rotasi faktor, dan

5. Penamaan faktor yang terbentuk.

Seluruh proses pengolahan data, mempergunakan alat bantu SPSS versi 23 for windows.

\section{HASIL DAN PEMBAHASAN}

\section{Uji Kualitas Data}

\section{Hasil Uji Validitas}

Uji signifikan dilakukan dengan membandingkan nilai $r$ hitung dengan $r$ tabel untuk degree of freedom $(\mathrm{df})=\mathrm{n}-2$, dimana sampel pada penelitian ini adalah 100 responden maka df nya dengan sig 0,05 adalah 0,1950

Berdasarkan data hasil penelitian pada tabel 1 di atas dapat dijelaskan bahwa dari 7 (tujuh) pernyataan di atas dinyatakan valid dan layak dijadikan instrument dalam penelitian ini dimana semua $r$ hitung item pernyataan lebih besar dari $r$ tabel yaitu 0,1950

\section{Tabel 1. Hasil Pengujian Validitas}




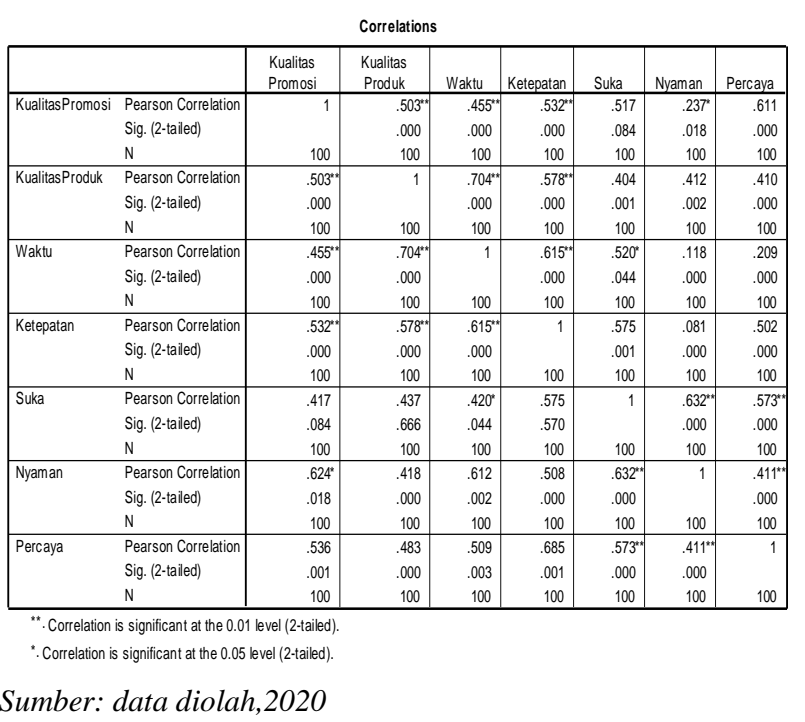

\section{Hasil Uji Reliabilitas}

Menurut Ghozali (2013:47) bahwa reliabilitas sebenarnya adalah alat untuk mengukur suatu kuesioner yang merupakan indikator dari variabel atau kontruks. Suatu kuaesioner dikatakan reliabel atau handal jika jawaban seseorang terhadap pernyataan adalah konsisten atau stabil dari waktu ke waktu. Suatu kontruks atau variabel dikatakan reliabel jika memberikan nilai Cronbach's Alpha > 0,70 , maka indikator yang terdapat pada suatu kuesioner dapat dikatakan reliabel. Berikut hasil uji reliabilitas dalam penelitian untuk setiap variabel dapat dilihat pada tabel dibawah ini:

Tabel 2. Hasil Pengujian Reliabilitas

Reliability Statistics

\begin{tabular}{|c|c|c|}
\hline $\begin{array}{l}\text { Cronbach's } \\
\text { Alpha }\end{array}$ & $\begin{array}{l}\text { Cronbach's } \\
\text { Alpha Based } \\
\text { on } \\
\text { Standardized } \\
\text { Items }\end{array}$ & $\mathrm{N}$ of ltems \\
\hline .838 & .838 & 4 \\
\hline
\end{tabular}

Sumber: data diolah, 2020

Berdasarkan data tabel.2 dapat disimpulkan bahwa Cronbach Alpha Faktor Promosi bernilai 0,838 yang berarti $>0,70$.

\section{Intreprestasi Faktor Promosi}

Data ini diolah dengan alat bantu software SPSS 16.0. kesembilan variabel yang telah dianggap valid dan reliabel, kemudian dimasukan ke dalam analisis faktor untuk diuji apakah nilainya lebih besar dari nilai KMO dan Barlett's Test yang di atas 0,5, hal ini merupakan tahap awal dalam analisis faktor. Berikut ini adalah tahap-tahap analisis faktor pada penelitian ini.

\section{Tahap1:}

Tahap awal dalam analisis faktor adalah Uji KMO dan bartlett's test dilakukan untuk mengetahui apakah faktor-faktor dalam penelitian valid atau tidak, pada tahap ini angka KMO dan Barlette's Test harus di atas $(0,5)$ dengan ktriteria:

1. $\mathrm{MSA}=1$, variabel tersebut dapat diprediksi tanpa kesalahan oleh variabel yang lain

2. MSA $>0,5$, variabel masih bisa diprediksi dan bisa dianalisis lebih lanjut.

3. MSA $<0,5$, variabel tidak bisa diprediksi dan tidak bisa dianalisis lebih lanjut, atau dikeluarkan dari variabel lainnya

Pada tabel 1.1 dapat dijelaskan bahwa tabel $\mathrm{KMO}$ and Bartlett's test menujukkan angka KMO Measure of sampling Adequaci (MSA) untuk Faktor Promosi adalah 0,780 $(>0,5)$ dengan (Sig) $0,000(<0,05)$. Hal ini menunjukkan kecukupan dan variabel memiliki korelasi yang kuat, data bisa dilanjutkan.

Tabel 3. KMO and Bartlett's Test

KMO and Bartlett's Test

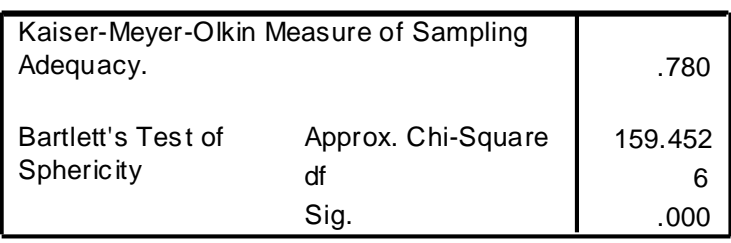

Sumber: data diolah,2020

\section{Tahap 2:}

Selanjutnya untuk mengetahui variabel mana yang dapat diproses lebih lanjut dan mana yang dikeluarkan dapat dilihat pada tabel Anti-image matrices. Pada tabel Anti-image Matrice di bawah, 
khusus pada bagian (Anti Image Correlation) terlihat angka yang bertanda (a) yang menandakan besaran MSA sebuah variabel.

Variabel Kualitas Promosi 0.838, Kualitas Produk 0.758, Waktu 0.742, Ketepatan dan kesesuaian 0.811. Nilai MSA masing-masing variabel besarnya $>0.5$ maka semua variabel dapat diproses lebih lanjut

Tabel.4.Anti -image Matrices

\begin{tabular}{|c|c|c|c|c|c|}
\hline \multicolumn{6}{|c|}{ Anti-image Matrices } \\
\hline & & $\begin{array}{l}\text { Kualitas } \\
\text { Promosi }\end{array}$ & $\begin{array}{l}\text { Kualitas } \\
\text { Produk }\end{array}$ & Waktu & Ketepatan \\
\hline \multirow{4}{*}{ Anti-image Covariance } & KualitasPromosi & .658 & -.118 & -.025 & -181 \\
\hline & KualitasProduk & -.118 & .449 & -.229 & -.085 \\
\hline & Waktu & -.025 & -.229 & .439 & -157 \\
\hline & Ketepatan & -181 & -.085 & -157 & .525 \\
\hline \multirow[t]{4}{*}{ Anti-image Correlation } & KualitasPromosi & $.838^{\mathrm{a}}$ & -.217 & -.047 & -308 \\
\hline & KualitasProduk & -.217 & $.758^{\mathrm{a}}$ & -.517 & -.175 \\
\hline & Waktu & -.047 & -.517 & $.742^{\mathrm{a}}$ & -327 \\
\hline & Ketepatan & -308 & -.175 & -.327 & $.811^{\mathrm{a}}$ \\
\hline
\end{tabular}

a. Measures of Sampling Adequacy(MSA)

Sumber: data diolah, 2020

Tahap 3:

Analisis communalities, analisis ini pada dasarnya adalah jumlah varians (bisa dalam presentase ) dari suatu variabel mula-mula yang bisa dijelaskan oleh faktor yang ada. persyaratan nilai communalities sendiri adalah lebih besar dari 0,5 (Santoso,2011). Berikut adalah hasil analisis communalities dari 17 variabel yang tersisa dan bisa dilakukan pengujian lebih lanjut.

\section{Tabel.5. Communaties}

Communalities
\begin{tabular}{|l|r|r|}
\hline & \multicolumn{1}{|c|}{ Initial } & Extraction \\
\hline KualitasPromosi & 1.000 & .749 \\
KualitasProduk & 1.000 & .731 \\
Waktu & 1.000 & .728 \\
Ketepatan & 1.000 & .692 \\
\hline
\end{tabular}

Extraction Method: Principal Component Analysis.

Sumber: data diolah, 2020
Dari Tabel Communalities dapat dijelaskan bahwa variabel Kualitas Promosi besarnya $0,749>0,50$. Nilai extraction untuk semua variabel lebih besar dari 0,05 , dengan demikian dapat disimpulkan bahwa semua varibel dapat dipakai untuk menjelaskan faktor.

Hal ini berarti sekitar $74,9 \%$ varians dari variabel kualitas promosi dapat dijelaskan oleh faktor yang terbentuk. Variabel ekonomi 0,731 hal ini berarti $73,1 \%$ varian dari variabel kualitas produk dapat dijelaskan oleh faktor yang terbentuk. Demikian juga untuk variabel yang lain. Semakin kecil nilai communalities berarti semakin lemah hubungannya dengan faktor yang terbentuk

\section{Tahap 4:}

Proses selanjutnya dari analisis faktor adalah melakukan pengujian Total Variance Explained. Menurut Santoso (2011 :85), bahwa tabel Total Variance Explained menggambarkan jumlah faktor yang terbentuk. Jumlah angka eigenvalue susunanya selalu diurutkan pada nilai yang terbesar sampai yang terkecil. Berikutmerupakan tabel hasil uji total variance explained sebagai berikut:

\section{Tabel.6. Total Variance Explained}

Total Variance Explained

\begin{tabular}{|l|r|r|r|r|r|r|}
\hline & \multicolumn{3}{|c|}{ Initial Eigenvalues } & \multicolumn{3}{|c|}{ Extraction Sums of Squared Loadings } \\
\cline { 2 - 7 } Component & \multicolumn{1}{|c|}{ Total } & \% of Variance & Cumulative \% & \multicolumn{1}{c|}{ Total } & \% of Variance & Cumulative \% \\
\hline 1 & 2.700 & 67.500 & 67.500 & 2.700 & 67.500 & 67.500 \\
2 & .593 & 14.815 & 82.315 & & & \\
3 & .422 & 10.552 & 92.867 & & & \\
4 & .285 & 7.133 & 100.000 & & & \\
\hline
\end{tabular}

Extraction Method: Principal Component Analysis.

Sumber: data diolah,2020

Pada tabel Total Variance Explained di atas menunjukkan ada 1 faktor yang terbentuk dari 4 variabel yang di masukkan. Masing-masing faktor eigenvalue $>1$. Faktor 1 eigen value sebesar 2,700 dengan variance $(67,5 \%)$

Nilai eigenvalue menggambarkan kepentingan relatif masing-masing faktor dalam menghitung varians dari 9 variabel yang di analisis. Bila semua 
variabel dijumlahkan bernilai 9 (sama dengan banyaknya variabel).

\section{$2,700 / 4 \times 100 \%=67,50 \%$}

Total varians apabila dari 4 variabel diekstrak menjadi 1 faktor adalah : 67,50\%

Besarnya varians yang mampu dijelaskan oleh faktor baru yang terbentuk adalah $67,50 \%$ sedangkan sisanya $32,50 \%$ dijelaskan oleh faktor lain yang tidak diteliti.

Langkah selanjutnya akan dijelaskan dalam grafik Screeplot yang akan menerangkan bahwa hubungan antara banyaknya faktor yang terbentuk dengan nilai eigenvalue dalam bentuk grafik.

Scree Plot

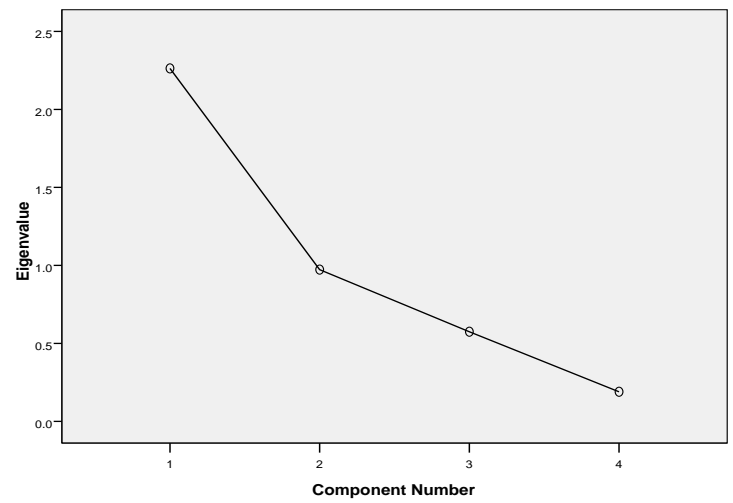

Sumber: data diolah, 2020

Gambar 2. Grafik Scree Plot

Gambar Scree Plot di atas dapat menunjukkan faktor yang terbentuk.dimana nilai eigenvalue $>1$. Dari gambar 1 ada 2 titik Component yang memiliki nilai Eigenvalue $>1$ maka diartikan bahwa hanya 1 faktor yang dapat terbentuk yaitu faktor kualitas promosi

\section{Tahap 4:}

Tahapan selanjutnya adalah menentukan itemitem yang dominan pada setiap komponen tersebut. Hal ini dapat dilihat dari tabel Component Matrix yang menunjukan distribusi item penelitian kelima faktor yang terbentuk. Kemudian dilakukan rotasi untuk menjelaskan distribusi variabel yang lebih jelas dan nyata, dibawah ini merupakan tabel yang menunjukkan hasil rotasi untuk memperjelas posisis sebuah variabel pada sebuah faktor.
Rotated Component matrix nilai loading faktor dari tiap-tiap variabel. Loading faktor merupakan besarnya korelasi antara faktor yang terbentuk dengan variabel tersebut. Rotasi yang dipakai adalah dengan metode varimax. Mekanisme rotasi varimax adalah dengan membuat korelasi item hanya dominan terhadap satu faktor. Untuk hasil Rotated Component Matrix tidak ada variabel yang bisa dirotasi karena hanya 1 variabel.

Dengan hasil pengolahan data yang telah dilakukan menunjukkan bahwa faktor kualitas promosilah yang sangat mempenagruhii perilaku pembelian online, apalgi masa COVID-19, yang mengharuskan tetap berada di rumah. Perusahaan atau pebisnis benar-benar memperhatikan faktor promosi agar produk yang dipasarkan bisa di terima dengan baik oleh konsumen. Dengan kemajuan teknologi seperti saat ini dengan berbagai media elektronik dan aplikasi bisa dimanfaatkan, maka tidak sulit bagi pemasar menawarkan produk secara online.

\section{KESIMPULAN}

Dari hasil analisis terlihat bahwa nilai KMO MSA (Keiser Meyer OlkinMeasure of Sampling Adequacy) pada tabel adalah 0.780. Hasil menunjukkan bahwa instrumen valid karena nilai KMO MSA (Keiser Meyer Olkin Measure of Sampling Adequacy) tidak melebihi batas signifikansi 0.50. Selain itu, Bartlett's Test of Sphericity menunjukkan nilai 159,452 dengan signifikansi 0,000 sehingga dapat diambil kesimpulan bahwa instrumen cukup valid. Dari 4 butir pertanyaan yang di analisis dan setelah melewati analisis KMO MSA, ternyata dari hasil analisis ekstraksi komputer menjadi 1 faktor (nilai eigen value > 1 menjadi 1 faktor). Faktor 1 yang mampu menjelaskan $67,50 \%$ variasi, Dari hasil rotasi dapat dilihat bahwa 4 variabel tersebut dapat direduksi menjadi 1 faktor yaitu : faktor kualitas promosi.

\section{DAFTAR PUSTAKA}

Ansari,Dedy Harahap Dan Dita Amanah, 2018, Perilaku Belanja Online Di Indonesia: Studi Kasus Jurnal Riset Manajemen Sains 
Indonesia (JRMSI) | Vol 9, No. 2, 2018 EISSN:2301-8313 http://Doi.Org/10.21009/JRMSI

\section{Badan Pusat Statistik (BPS), 2020}

Gutam R, Singh RD, Sharma VP, Siddhartha R, Chand P, Kumar R. Biocompatibility of Polymethylmethacrylate Resins Used in Dentistry. J Biomed Mater Res Part B; 2012:1-7.

Ghozali, Imam, 2016, Aplikasi Analisis Multibariete Dengan Program IBM SPSS Universitas Diponegoro.

Handoko, T. Hani. 2014. Manajemen Personalia dan Sumber Daya Manusia.BPFE, Yogyakarta

Iranita, 2019, Analisis Pengaruh Brand Equity Untuk Meningkatkan Minat Beli Ulang Dan Word Of Mouth (Studi Kasus Batik Gonggong Tanjungpinang), Vol.3. nomor 2.2019, hal.40-55, Bahtera Inovasi, ISSN.2613-9243

Kotler, P. \& Keller, K. L. (2013). Marketing manage-ment. 14th Edition. New Jersey: Pearson Horizon.

2013, Manajemen Pemasaran, Jilid

$2\left(13^{\text {th }} \mathrm{Ed}\right)$, Jakarta: Erlangga

Kotler, P.,\& Armstrong.G, 2014, Prinsip-prinsip Pemasaran Jilid 1 (13 $^{\text {th }}$ Ed), Jakarta : Erlangga

Kuncoro, Mudrajat, 2009, Metode Riset untuk Bisnis dan Ekonomi,,Jakarta : Erlangga

Lo, S.-K., Chou, Y.-J. \& Teng, C.-I., 2013. Source effect of advertised reference price influences on transaction value in online shopping environments, Electron Commer Res, pp. 411-421

Partha, \& Sukawati, 2016, Peran Promosi Dalam Memediasi Lingkungan Pemasaran OnlineTerhadap Perilaku Pembelian
Online.: E-Jurnal Manajemen Unud, Vol. 5, No. 5, 3053-3079. ISSN : 2302-8912

Putra, A. A. N. B. M. \& Kusuma, A. A. G. A. A., 2015. Pengaruh Kecanduan Internet, Daya Tarik Promosi dan Kepemilikan Kartu Kredit terhadap Perilaku Pembelian Impulsif Online. E-Jurnal Manajemen Universitas Udayana, 4 (1):209-227

Sanjaya, S. (2015). Pengaruh Promosi Dan Merek Terhadap Keputusan Pembelian Pada PT. Sinar Sosro Medan. Ilmiah Manajemen Dan Bisnis, 16(02), 108-122

Sarwono, J. \& Prihartono. (2012). Perdagangan online: Cara bisnis di internet. Jakarta: PT Media Elex Komputindo.

Soegiyono, 2014, Metode Penelitian Kuantitatif, Kualitatif dan $R \& D$, Bandung: Alfabeta

Tjiptono, Fandy. 2014, PemasaranJasa-Prinsip, Penerapan,dan Penelitian, Andi Offset, Yogyakarta.

Widiyanto, Ibnu Dan Sri Lestari Prasilowati2, Perilaku Pembelian Melalui Internet, Jmk, Vol. 17, No. 2, September 2015, 109-112. Issn 1411-1438 Print / Issn 2338-8234 Online, Doi: 10.9744/Jmk.17.2.109-112 